\title{
Prevention of lethal hepatic injury in Long-Evans Cinnamon (LEC) rats by D-galactosamine hydrochloride
}

\author{
Toshihiro Otsuka', Keisuke Izumi ${ }^{2}$, Itsuo Tokunaga ${ }^{3}$, Takako Gotohda ${ }^{3}$, Kaneshige Ipposhi ${ }^{4}$, \\ Yoshiharu Takiguchi ${ }^{4}$, Shinya Kaneda ${ }^{2}$, Nobuo Satake ${ }^{2}$, Takamasa Ohnishi ${ }^{2}$ Seiki Tashiro', \\ and Mitsuo Shimada ${ }^{1}$ \\ ${ }^{1}$ Department of Digestive and Pediatric Surgery, ${ }^{2}$ Department of Molecular and Environmental Pathol- \\ ogy, Department of Legal Medicine, and ${ }^{4}$ Department of Clinical Pharmacology, Institute of Health \\ Biosciences ,The University of Tokushima Graduate School, Tokushima , Japan
}

\begin{abstract}
Repeated injections of D-galactosamine hydrochloride (GalN) increase the survival rate of Long-Evans Cinnamon (LEC) rats, an animal model of Wilson's disease. The aim of the present study was to investigate the mechanism of GalN for prevention of spontaneous lethal hepatic injury in LEC rats. Male LEC rats were given a single subcutaneous injection of $300 \mathrm{mg} / \mathrm{kg}$ of GalN or vehicle $(0.9 \% \mathrm{NaCl})$ at 14 weeks, and killed at 28 weeks of age. Next, 6 -week-old male $\mathrm{LEC}$ rats were given weekly subcutaneous injections of $300 \mathrm{mg} / \mathrm{kg}$ of GalN or vehicle for 3 or 12 weeks, and their hepatic 8-hydroxydeoxy-2'-guanosine (8-OHdG), glutathione peroxidase (GPX), and catalase activities were measured. None of GalN-treated rats died of hepatic injury (0/12), whereas the mortality rate of control rats given $0.9 \% \mathrm{NaCl}$ was $17 \%(2 / 12)$. GalN administration for 12 weeks decreased the hepatic 8-OHdG, and GalN administration for either 3 or 12 weeks increased the glutathione peroxidase activity. GalN administration increased the serum level of alanine aminotransferase, and accelerated megalocytic degeneration of the hepatocytes. GalN treatment is effective in preventing lethal hepatitis in LEC rats and decrease of oxidative DNA damage by GalN plays an important role in increase of the survival rate. 53:81-86, February, 2006
\end{abstract}

Keywords : LEC rat, 8-OHdG, glutathione peroxidase, D-galactosamine hydrochloride, Wilson's disease

\section{INTRODUCTION}

Long-Evans Cinnamon (LEC) rats have a genetic defect in the p-type copper transport ATPase gene $($ Atp $7 b$ ), and excess copper accumulates in their liver as in patients with Wilson's disease (1-4). LEC rats develop toxic hepatitis with severe jaundice spontaneously at about $4-6$ months of age(2). The mortality rate at 6 months is about $10-20 \%$ in males, and $40-50 \%$

Received for publication September 21, 2005 ; accepted December $5,2005$.

Address correspondence and reprint requests to Keisuke Izumi, Department of Molecular and Environmental Pathology, Institute of Health Biosciences, The University of Tokushima Graduate School, 3-18-15 Kuramoto-cho, Tokushima 770-8503, Japan and Fax : +81-88-633-7067. in females. Chelation therapy (5,6), and feeding of copperdeficient diet (7) can inhibit hepatic injury. We reported that induction of hepatocyte regeneration by repeated injections of D-galactosamine hydrochloride (GalN) completely inhibited lethal hepatitis in LEC rats without decreasing the hepatic copper concentration(8). Administration of GalN to rats causes dose-dependent hepatocellular necrosis and compensatory hepatocyte proliferation (9). In our study, the 5-bromo-2'- deoxyuridine (BrdU) labeling index of hepatocytes in rats treated with $300 \mathrm{mg} / \mathrm{kg}$ of GalN was 4.6 times that in the controls given vehicle on day 2 , and decreased to close to the control level on day 7 (8).

Free radicals are thought to contribute to the pathogenesis of liver injury induced by various he- 
patotoxins such as alcohol (10), carbon tetrachloride(11), paracetamol (12) and GalN (13), and GalN has been used for induction of liver cell injury in rodents $(9,14)$. This injury is similar to that in humans with acute viral hepatitis. GalN depletes the uridine nucleotide pool and inhibits RNA synthesis (15). The oxidative DNA damage caused by copper ions includes mutagenesis, strand breaks and 8-hydroxydeoxy2'-guanosine (8-OHdG) formation (16-18). The amount of $8-\mathrm{OHdG}$, a reliable marker of hydroxy radical-induced DNA damage (19), increases in the DNA in the liver and kidney of LEC rats, especially in the period of severe hepatitis (20).

We suggested that GalN decreases liver injury by inhibition of copper-mediated free-radical production. In the present study, we investigated 1) the effect of a single dose of GalN on the mortality rate and 2) the effect of repeated injections of GalN on hydroxy radical-induced DNA damage and hepatic antioxidant enzyme activities in LEC rats.

\section{METHODOLOGY}

\section{Animals}

The male LEC/Tj rats used in Experiment 1 were supplied from the Institute for Animal Experimentation, The University of Tokushima School of Medicine, while male LEC rats used in Experiment 2 were obtained from Charles River Japan, Inc., Kanagawa. Animals were housed three to a plastic cage with sterilized woodchips for bedding in an air-conditioned room at $23 \pm 2^{\circ} \mathrm{C}$ and $55 \pm 10 \%$ humidity with a $12 \mathrm{~h}$ light/ dark cycle, and given pellet diet (Oriental Yeast Co., Tokyo, Japan) and tap water ad libitum. Experiments were conducted according to the Guidelines for the Care and Use of Laboratory Animals of The University of Tokushima School of Medicine.

\section{Experiment 1}

Male LEC rats ( $\mathrm{n}=15)$ were given single subcutaneous injections of $300 \mathrm{mg} / \mathrm{kg}$ GalN (Wako Pure Chemical Industries, Osaka, Japan) or vehicle ( $2 \mathrm{ml} / \mathrm{kg}$ $0.9 \% \mathrm{NaCl}$ ) at 14 weeks old, and killed at 28 weeks old under ether anesthesia. Body weights were recorded once a week.

\section{Experiment 2}

Six-week-old rats $(\mathrm{n}=8)$ were given weekly subcutaneous injections of $300 \mathrm{mg} / \mathrm{kg}$ of GalN in $0.9 \%$
$\mathrm{NaCl}$ or $0.9 \% \mathrm{NaCl}$ only for 3 or 12 weeks and were killed 7 days after the final injection. Blood samples were collected with an anticoagulant heparin sodium and centrifuged at $1,500 \mathrm{xg}$ for $15 \mathrm{~min}$ and the plasma was stored at $-80^{\circ} \mathrm{C}$. Part of the excised liver was immersed in liquid nitrogen and stored at $-80^{\circ} \mathrm{C}$ until use. The remaining liver tissue was fixed in $10 \%$ buffered formalin for histological examination.

\section{Measurement of 8-OHdG}

Liver was homogenized, and DNA was extracted with isopropanol by using a DNA Extractor WB kit (Wako Pure Chemical Industries). The 8-OHdG content of the liver DNA was measured with an ELISA kit (Japan Institute for the Control of Aging, Shizuoka, Japan) as follows. Fifty $\mu$ l of primary monoclonal antibody and $50 \mu \mathrm{l}$ of sample or standard solution were added to microtitre plates precoated with 8-OHdG. The plates were sealed tightly, incubated at $37^{\circ} \mathrm{C}$ for 1 hour, and then washed with $250 \mu$ l of phosphatebuffered saline. One hundred $\mu \mathrm{l}$ of secondary antibody conjugated to horseradish peroxidase was then added to each well, incubated, and washed. Then $100 \mu \mathrm{l}$ of enzyme substrate was added to each well, and the reaction was ended by addition of $100 \mu \mathrm{l}$ of $1 \mathrm{~N}$ phosphoric acid. Absorbance readings at $450 \mathrm{~nm}$ were taken $3 \mathrm{~min}$ later in a spectrophotometer. The amount of $8-\mathrm{OHdG}$ in each rat was calculated by comparison with a standard curve.

\section{Determinations of enzyme activities in tissues}

Glutathione peroxidase (GPX) activity was assayed using t-butyl hydroperoxide as a substrate. Both sample and reference cuvettes contained $0.01 \mathrm{~mol} /$ liter of Tris- $\mathrm{HCl}, \mathrm{pH}$ 8.0, $0.5 \mathrm{mmol} /$ liter of ethylene diamine tetra-acetic acid, $0.2 \mathrm{mmol} /$ liter of NADPH, $1 \mathrm{U}$ of glutathione reductase, $2 \mathrm{mmol} /$ liter of glutathione (GSH), and an appropriate amount of enzyme in $1 \mathrm{ml}$. The oxidation of nicotinamide adenine dinucleotide phosphate (NADPH) by t-butyl hydroperoxide (70 umol/ liter), added to the sample cuvette only, was followed spectrophotometrically at $340 \mathrm{~nm}$ at $37^{\circ} \mathrm{C}$. An additional blank containing all components except the enzyme was used to correct for nonenzymatic oxidations of GSH and NADPH by t-butyl hydroperoxide (21).

Catalase activity was measured in a $20 \%$ homogenate by the method of Chance et al (22). The breakdown of $\mathrm{H}_{2} \mathrm{O}_{2}$ was determined spectrophotometrically by following the decrease of absorbance at $240 \mathrm{~nm}$. Protein levels were assayed by the method of Lowry et al (23). 
Serum aspartate aminotransferase (AST), alanine aminotransferase $(A L T)$, and lactate dehydrogenase $(L D H)$

The serum levels of AST, ALT, and LDH were measured in Otsuka Assay Laboratories, Tokushima, Japan.

\section{Statistical analysis}

All data are expressed as means \pm SD. Statistical significance was analyzed by the unpaired $t$ test.

\section{RESULTS}

After 12 weeks, toxic hepatitis develops in LEC rats. In Experiment 1, the body weight decreased in both GalN-treated and control rats from 15 weeks of age, and two control rats died of hepatic injury with severe jaundice at 16 and 17 weeks (Figure 1). The survival rate was 12/12 (100\%) in GalN-treated rats and 10/12 (83\%) in control rats given vehicle. After week 17 , the average body weights in control rats were lower than those of GalN-treated rats. Histologically, the livers of GalN-treated and control rats showed similar marked megalocytic changes.

In Experiment 2, the 8-OHdG levels in rats treated with either $\mathrm{GalN}$ or $0.9 \% \mathrm{NaCl}$ for 12 weeks were higher than those at 3 weeks. GalN treatment for 12 weeks decreased the amount of $8-\mathrm{OHdG}$ slightly less than that after treatment for 3 weeks $(P<0.05$,
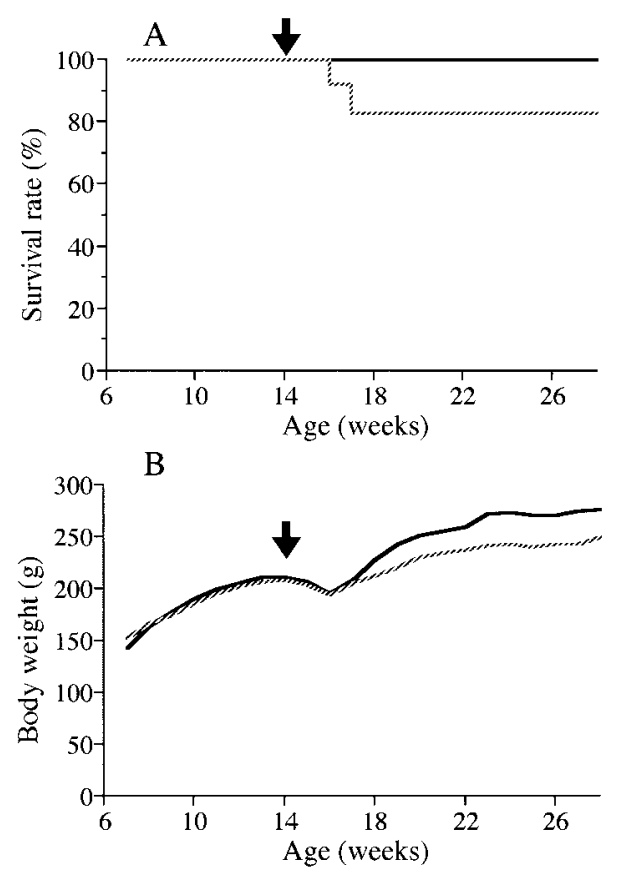

Fig.1. Survival rates (A) and growth curves (B) of male LEC rats given a single subcutaneous injection of $300 \mathrm{mg} / \mathrm{kg}$ GalN or $0.9 \% \mathrm{NaCl}$ (Experiment 1).

: GalN ; ;
Figure 2). GalN treatment for either 3 weeks or 12 weeks significantly increased the GPX level $(P<0.05$ and $P<0.01$, respectively), but not that of catalase. GalN treatment for 12 weeks increased the serum AST and ALT $(P<0.05$ and $P<0.01$, respectively), but not the LDH activity (Figure 3).There were no histological differences
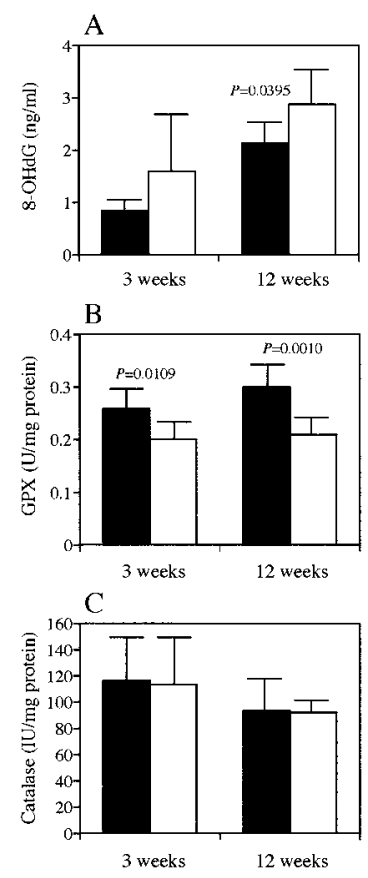

Fig.2. Amounts of 8-OHdG, GPX and catalase in the liver of LEC rats treated for 3 and 12 weeks (Experiment 2). (A) 8-OHdG ( $\mathrm{n}=7$ ), (B) GPX $(\mathrm{n}=7),(\mathrm{C})$ catalase $(\mathrm{n}=6)$

$\square$, GalN ; $\square, \mathrm{NaCl}$
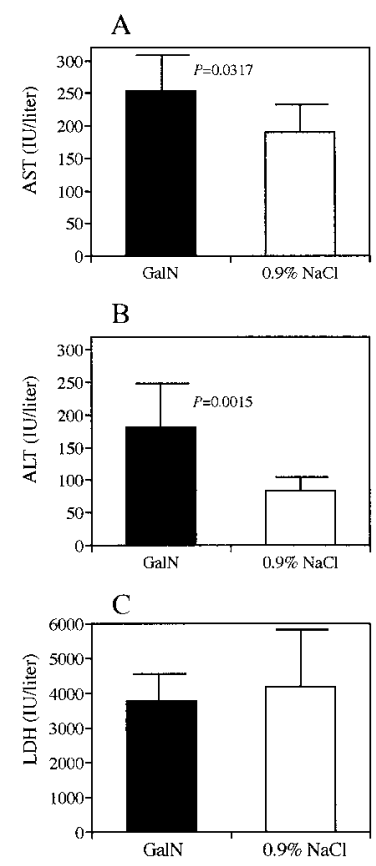

Fig.3. Serum AST, ALT and LDH in the liver of LEC rats in week 3 and 12 (Experiment 2).

$\operatorname{AST}(\mathrm{n}=8), \operatorname{ALT}(\mathrm{n}=8)$ and LDH $(\mathrm{n}=8)$

口, GalN ; $\square, \mathrm{NaCl}$ 
between the livers of rats given GalN and those given $0.9 \% \mathrm{NaCl}$ for 3 weeks, but peculiar megalocytic degeneration of the hepatocytes appeared in rats given GalN for 12 weeks (Figure 4).
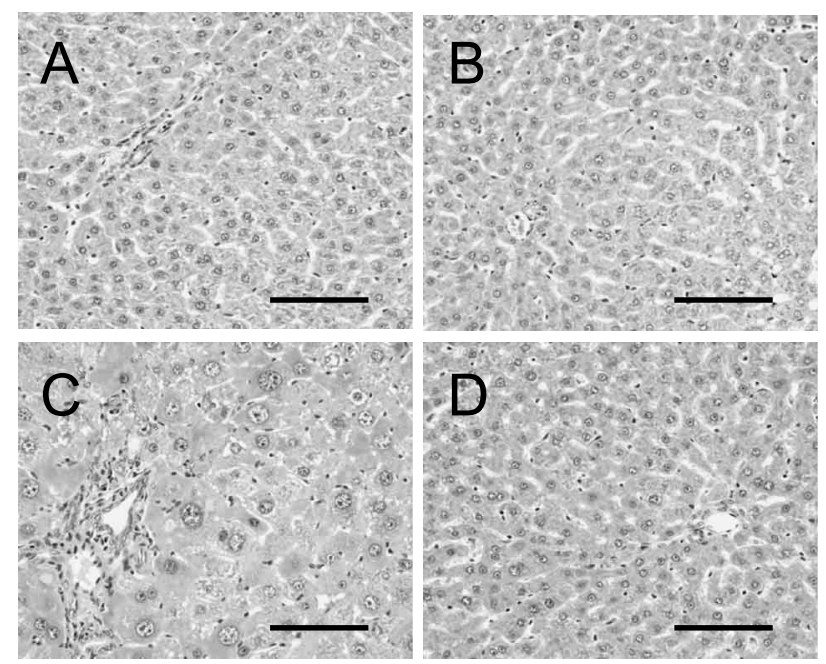

Fig.4. Histological appearances of the liver of LEC rats.(A) GalN for 3 weeks, (B) $0.9 \% \mathrm{NaCl}$ for 3 weeks, (C) GalN for 12 weeks, (D) $0.9 \% \mathrm{NaCl}$ for 12 weeks.

Liver cell enlargement with large nuclei was observed in rats treated with GalN for 12 weeks.

bar, $100 \mu \mathrm{m}$.

\section{DISCUSSION}

We and others have observed factors intensifying and inhibiting hepatic injury in LEC rats, as shown in Table $1(5-8,24-32)$. The inhibitory factors may be divided into three groups: 1 ) those reducing the hepatic copper concentration, 2) antioxidants or free-radical scavengers, and 3) those inducing hepatocyte regeneration with or without eventual hepatic copper reduction. The effect of iron-deficient diet on hepatic injury is controversial, because it may increase copper absorption from the intestine in female LEC rats (33). Dipyrone, an antipyretic drug, is a hepatotoxic chemical. We have found that lethal hepatitis in LEC rats is completely prevented by the injection of $\mathrm{N}$ diethylnitrosamine, a hepatotoxic agent and hepatocarcinogen (unpublished data). Thus, it is likely that GalN prevents lethal hepatitis in LEC rats.

We found in Experiment 1 that a single injection of GalN into LEC rats just before the onset of lethal hepatic injury increased the survival rate and prevented inhibition of body weight gain. The present data suggest that induction of hepatocyte regeneration not only by long-term repeated injections (8), but also by a single injection of GalN is effective in preventing lethal hepatitis in LEC rats. This paradoxical finding might be applied in the prevention of hepatic failure in Wilson's disease

Table 1. Intensifying and Inhibiting Factors for Spontaneous Hepatic Injury in LEC Rats

\begin{tabular}{|c|c|c|c|}
\hline & Chemical/factor & Mechanism & Reference No. \\
\hline \multirow[t]{4}{*}{ Intensification } & Phenobarbital & & 24 \\
\hline & Clofibrate & & 24 \\
\hline & Choline-deficient diet & & 25 \\
\hline & Soy protein & & 26 \\
\hline \multirow[t]{12}{*}{ Inhibition } & D-Penicillamine & copper chelation & 5 \\
\hline & Trientine & copper chelation & 6 \\
\hline & Copper-deficient diet & reduction of hepatic copper & 7,28 \\
\hline & Iron-deficient diet & reduction of hepatic iron & 29 \\
\hline & Zinc acetate & inhibition of copper absorption & 30 \\
\hline & Ascorbic acid & antioxidant & 27 \\
\hline & DL- $\alpha$-Lipoic acid & antioxidant & 31 \\
\hline & $\alpha$-Phenyl-t-butyl-nitrone & radical scavenger & 32 \\
\hline & Dipyrone & hepatocyte regeneration & 24 \\
\hline & D-Galactosamine $\mathrm{HCl}$ & hepatocyte regeneration & 8,24 \\
\hline & Partial hepatectomy & hepatocyte regeneration and & 8 \\
\hline & & reduction of hepatic copper & \\
\hline
\end{tabular}


and other types of fulminant hepatitis, although more practical methods must be developed.

In Experiment 2, repeated injections of GalN decreased the 8-OHdG level, and increased the activity of GPX, but did not change the catalase activity of the liver. It is known that the activities of antioxidant enzymes, such as GPX and catalase, are decreased in LEC rats $(34,35)$. We found previously that repeated injections of $300 \mathrm{mg} / \mathrm{kg}$ of GalN for 5,12 , or 25 weeks did not decrease the hepatic copper concentration (8). The present study showed that GalN increased AST and ALT and accelerated copper-induced megalocytic degeneration of hepatocytes. Therefore, we suggest that GalN administration improved the survival rate of LEC rats by decreasing 8-OHdG and increasing GPX without decrease of the copper concentration.

\section{REFERENCES}

1. Sasaki M, Yoshida MC, Kagami K, Takeichi N, Kobayashi H, Dempo K, Mori M : Spontaneous hepatitis in an inbred strain of Long-Evans rats. Rat News Lett 14 : 4-6, 1985

2. Yoshida MC, Masuda R, Sasaki M, Takeichi N, Kobayashi H, Dempo K, Mori M : New mutation causing hereditary hepatitis in the laboratory rat. J Hered $78: 361-365,1987$

3. Li Y, Togashi Y, Sato S, Emoto T, Kang J-H, Takeichi N, Kobayashi H, Kojima Y, Une Y, Uchino J:Spontaneous hepatic copper accumulation in Long-Evans Cinnamon rats with hereditary hepatitis. J Clin Invest 87 : 1858-1861, 1991

4. Wu J, Forbes JR, Chen HS, Cox DW:The LEC rat has a deletion in the copper transporting ATPase gene homologous to the Wilson disease gene. Nature Genet 7 : 541-545, 1994

5. Togashi Y, Li Y, Kang J-H, Takeichi N, Fujioka Y, Nagashima K,Kobayashi H:D-Penicillamine prevents the development of hepatitis in Long-Evans Cinnamon rats with abnormal copper metabolism. Hepatology $15: 82-87,1992$

6. Sone K, Maeda M, Wakabayashi K, Takeichi N, Mori M, Sugimura T, Nagao M : Inhibition of hereditary hepatitis and liver tumor development in Long-Evans Cinnamon rats by the copperchelating agent trientine dihydrochloride. Hepatology 23 : 764-770, 1996

7. Sugawara N, Sugawara C:A copper deficient diet prevents hepatic copper accumulation and dysfunction in Long-Evans Cinnamon (LEC) rats with an abnormal copper metabolism and hereditary hepatitis. Arch Toxicol 69:137- 140, 1994

8. Jiao Z, Ohnishi T, Bando Y, Chone Y, Kitaura K, Uehara H, Suzuki Y, Nakamura T, Izumi K: Effects of D-galactosamine hydrochloride and partial hepatectomy on spontaneous hepatic injury and hepatocarcinogenesis in Long-Evans Cinnamon rats. Jpn J Cancer Res 90:496-504,1999

9. Keppler D, Lesch R, Reutter W, Decker K: Experimental hepatitis induced by D-galactosamine. Exp Mol Pathol 9 : 279-290, 1968

10. Uysal M, Özdemirler G, Kutalp G, Oz H : Mitochondrial and microsomal lipid peroxidation in rat liver after acute acetaldehyde and ethanol intoxication. J Appl Toxicol 9 : 155-158, 1989

11. Uzel N, Özdemirler G, Sivas A, Uysal M:Effects of $\mathrm{CCl}_{4}$-induced lipid peroxidation and diethyl maleate-induced glutathione depletion on plasma lecithin cholesterol acyl transferase activity in rats. Biochem Arch 5 : 353-358, 1989

12. Özdemirler G, Aykac G, Uysal M, Oz H : Liver lipid peroxidation and glutathione-related defense enzyme systems in mice treated with paracetamol. J Appl Toxicol 14 : 297-299, 1994

13. Seckin S, Kocak-Toker N, Uysal M, Oz B : The role of lipid peroxidation and calcium in galactosamine induced toxicity in the rat liver. Res Commun Chem Pathol Pharmacol 80 : 117-120, 1993

14. Decker K, Keppler D : Galactosamine induced liver injury. In:Popper H, Schaffner F, eds. Progress in Liver Diseases IV. Grune and Stratton, New York, 1972, pp.183-199

15. Keppler D, Pausch J, Decker K: Selective uridine triphosphate deficiency induced by D-galactosamine in liver and reversed by pyrimidine nucleotide precursors. Effect on ribonucleic acid synthesis. J Biol Chem 249 : 211-216, 1974

16. Sagripanti JL, Kraemer KH:Site-specific oxidative DNA damage at polyguanosines produced by copper plus hydrogen peroxide. J Biol Chem 264 : 1729-1734, 1989

17. Tkeshelashvili LK, McBride T, Spence K, Loeb LA:Mutation spectrum of copper-induced DNA damage. J Biol Chem 266 : 6401-6406, 1991

18. Toyokuni S, Sagripanti JL:Association between 8-hydroxy-2'-deoxyguanosine formation and DNA strand breaks mediated by copper and iron. Free Radic Biol Med 20 : 859-864, 1996

19. Kasai $\mathrm{H}$ : Analysis of a form of oxidative DNA damage, 8-hydroxy-2'-deoxyguanosine, as a marker of cellular oxidative stress during carcinogenesis. Mutat Res 387 : 147-163, 1997 
20. Yamamoto F, Kasai H, Togashi Y, Takeichi N, Hori T, Nishimura S:Elevated level of 8hydroxydeoxyguanosine in DNA of liver, kidneys, and brain of Long-Evans Cinnamon rats. Jpn J Cancer Res 84 : 508-511, 1993

21. Takahashi K, Cohen HJ : Selenium-dependent glutathione peroxidase protein and activity: immunological investigations on cellular and plasma enzymes. Blood 68 : 640-645, 1986

22. Chance B, Sies H, Boveris A: Hydroperoxide metabolism in mammalian organs. Physiol Rev 59: 527-605, 1979

23. Lowry OH, Rosebrough NJ, Farr AL, Randall RJ: Protein measurement with the Folin phenol reagent. J Biol Chem 193 : 265-275, 1951

24. Izumi K, Uehara H, Otsuka H, Matsumoto K : Inhibitory and intensifying effects of long-term exposure to chemicals on spontaneous hepatic injury in LEC rats. In : Mori M, Yoshida MC, Takeichi N, Taniguchi N, eds. The LEC Rat: A New Model for Hepatitis and Liver Cancer. Springer-Verlag, Tokyo, 1991, pp.114-119

25. Sugiyama T, Matsunaga M, Jain SK, Jain S, Ikeda Y, Taniguchi N:Enhancing effect of a cholinedeficient diet on alterations of hepatic drugmetabolizing enzymes in hepatitis- and hepatomapredisposed rats (LEC rats). Jpn J Cancer Res 82 : 390-396, 1991

26. Yonezawa K, Nunomiya S, Daigo M, Ogra Y, Suzuki KT, Enomoto K, Nakagama H, Yoshikawa K, Nagao M: Soy protein isolate enhances hepatic copper accumulation and cell damage in LEC rats. J Nutr 133 : 1250-1254, 2003

27. Hawkins RL, Mori M, Inoue M, Torii K: Proline, ascorbic acid, or thioredoxin affect jaundice and mortality in Long Evans Cinnamon rats. Pharmacol Biochem Behav 52 : 509-515, 1995

28. Sawaki M, Hattori A, Tsuzuki N, Sugawara N, Enomoto K, Sawada N, Mori M : Chronic liver injury promotes hepatocarcinogenesis of the LEC rat. Carcinogenesis $19:$ 331-335, 1998

29. Kato J, Kobune M, Kohgo Y, Sugawara N, Hisai H, Nakamura T, Sakamaki S, Sawada N, Niitsu Y: Hepatic iron deprivation prevents spontaneous development of fulminant hepatitis and liver cancer in Long-Evans Cinnamon rats. J Clin Invest 98 : 923-929, 1996

30. Sugawara N, Katakura M, Sugawara C: Preventive effect of zinc compounds, polaprezinc and zinc acetate against the onset of hepatitis in LongEvans Cinnamon rat. Res Commun Mol Pathol Pharmacol 103 : 167-176, 1999

31. Yamamoto H, Watanabe T, Mizuno H, Endo K, Fukushige J, Hosokawa T, Kazusaka A, Fujita S : The antioxidant effect of DL- $\alpha$-lipoic acid on copper-induced acute hepatitis in Long-Evans Cinnamon (LEC) rats. Free Radic Res 34:69-80, 2001

32. Yamashita T, Ohshima H, Asanuma T, Inukai N, Miyoshi I, Kasai N, Kon Y, Watanabe T, Sato F, Kuwabara M : The effects of $\alpha$-phenyl-tert-butyl nitrone $(\mathrm{PBN})$ on copper-induced rat fulminant hepatitis with jaundice. Free Radic Biol Med 21 : 755-761, 1996

33. Sugawara N, Sugawara C:An iron-deficient diet stimulates the onset of the hepatitis due to hepatic copper deposition in the Long-Evans Cinnamon (LEC) rat. Arch Toxicol 73 : 353-358, 1999

34. Ohhira M, Ono M, Ohhira M, Sekiya C, Namiki M, Fujimoto Y, Nagao M, Mori M:Changes in free radical-metabolizing enzymes and lipid peroxides in the liver of Long-Evans with cinnamon-like coat color rats. J Gastroenterol 30 : 619-623, 1995

35. Yamamoto H, Hirose K, Hayasaki Y, Masuda M, Kazusaka A, Fujita S:Mechanism of enhanced lipid peroxidation in the liver of Long-Evans Cinnamon (LEC) rats. Arch Toxicol 73 : 457-464, 1999 